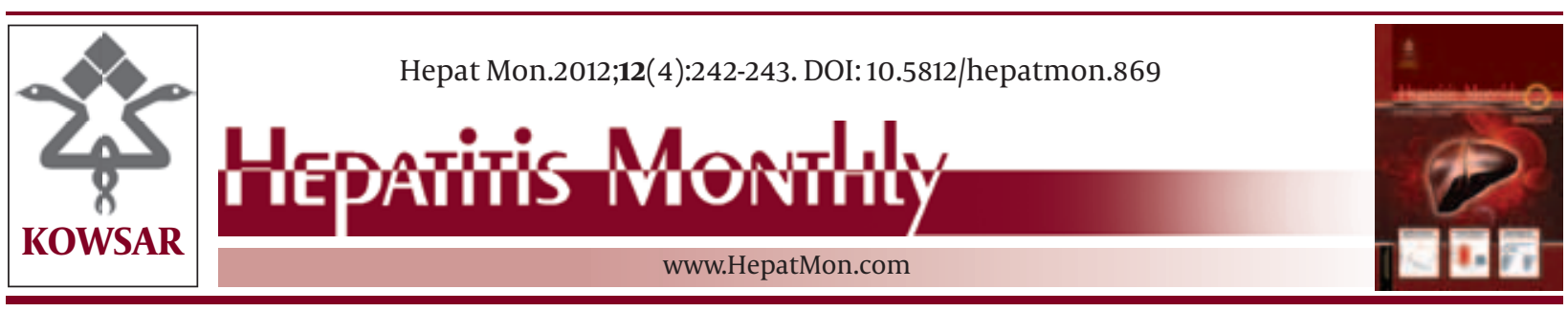

\title{
Occult Hepatitis B Virus Infection Among Hemodialysis Patients
}

\author{
Seyed Moayed Alavian ${ }^{1^{*}}$ \\ ${ }^{1}$ Baqiyatallah Research Center for Gastroenterology and Liver Diseases, Baqiyatallah University of Medical Sciences, Tehran, IR Iran
}

\begin{tabular}{l}
\hline A R T I C L E I N F O \\
\hline Article type: \\
Editorial \\
\hline Article history: \\
Received: 01 Apr 2012 \\
Revised:16 Apr 2012 \\
Accepted: 25 Apr 2012 \\
\hline Keywords: \\
Hemodialysis \\
Viruses \\
Hepatitis B \\
\hline
\end{tabular}

Implication for health policy/practice/research/medical education:

Occult hepatitis B infection is important entity in hemodialysis patients and study of this article is recommended to the epidemiologists, hepatologists, virologists, nephrologists and other researchers who are interested in the field of public health.

- Please cite this paper as:

Alavian SM. Occult Hepatitis B Virus Infection Among Hemodialysis Patients. Hepat Mon. 2012;12(4):242-3. DOI: 10.5812/hepatmon.869

Copyright $\odot 2012$ Kowsar Corp. All rights reserved.

Occult hepatitis $\mathrm{B}(\mathrm{OHB})$ is not a new entity and there are many reports of patients with hepatitis B virus (HBV) evidence replication in the absence of detectable hepatitis B surface antigen (HBsAg) and occasionally other HBV serologic markers (1). After introducing highly sensitive and specific tests for HBs Ag and HBV DNA, the diagnosis of $\mathrm{OBH}$ is easier and the importance of clinical entity of $\mathrm{OBH}$ is more controversial. In this issue of Hepatitis Monthly, Abu El Makarem reported the prevalence of occult hepatitis B virus infection in hemodialysis patients from Egypt with considering the hepatitis C Virus (HCV) Infection (2). Prevalence of HBV DNA detection in hemodialysis patients was reported $4.1 \%$, and the authors concluded occult HBV infection (OBI) in those patients. They did not find any correlation between the variables and OBI. I would like to mention that finding the HBV DNA in the serum is not parallel to OBI and it is better to use the term of OHB instead of OBI in their cases. Moreover, in a literature review it has been suggested that occult $\mathrm{HBV}$ in patients with chronic HCV infection has a possible correlation with higher grades of liver damage or even

* Corresponding author: Seyed Moayed Alavian, Baqiyatallah Research Center for Gastroenterology and Liver Diseases, Mollasadra, Vanak sq. Baqiyatallah University of Medical Sciences, Tehran, IR Iran. Tel: +982188945186, Fax:+98-2188945188,E-mail: Alavian@thc.ir

DOI:10.5812/hepatmon.869

Copyright $\odot 2012$ Kowsar Corp. All rights reserved. developing hepatocellular carcinoma (3). In addition, chronic HCV infection is frequently reported with occult HBV infection, due to almost the same route of transmission and risk factors (3).

Egypt has the highest prevalence of HCV infection in the world (4). However the detection of $\mathrm{OBH}$ requires assays with the highest sensitivity and specificity and a lower limitation to detect less than $10 \mathrm{IU} / \mathrm{ml}$ HBV DNA (5). It is very interesting for us that the authors declared they used the real time PCR kit (COBAS Taqman HBV Test; cutoff detection: $6 \mathrm{IU} / \mathrm{mL}$ ) that is a very sensitive test in their study. As they presented, the prevalence of anti-HBc $\mathrm{Ab}$ as well as the history of HBV infection in group one (HCV RNA positive ones) was more common than group two (HCV RNA negative). This condition is relatively more common in patients with HCV infection that seems to be related to influence on the replicative capacity and latency of HBV and the main risk factors for airing these infections. The authors did not find any relation between the ALT level and the presence of HBV DNA in the serum, In my opinion the liver biopsy provides more relevant data than ALT in liver damage specifically in hemodialysis patients (6).

End-stage renal disease (ESRD) is a significant problem in almost all countries and the prevalence has increased considerably in developing countries especially in Middle East countries. The prevalence of HCV infection among 
hemodialysis patients differs in different parts of Middle East countries which is $48 \%$ in Egypt (7). The prevalence of $\mathrm{OBH}$ in hemodialysis patients varies from $0 \%$ to more than $20 \%$ in different studies and it requires more investigations with more sample size to find out OBH impact in transmission of HBV infection in hemodialysis centers.

\section{Acknowledgments}

None declared.

\section{Authors' Contribution}

Author contributed $100 \%$ to prepare this article.

\section{Financial Disclosure}

None declared.

\section{Funding/Support}

None declared.

\section{References}

1. Honarkar Z, Alavian SM, Samiee S, Saeedfar K, Zali MR. Occult hepatitis B among chronic liver disease patients. Saudi Med J. 2005;26(4):601-6.

2. Abu El Makarem MA, Abdel Hamid M, Abdel Aleem A, Ali A, Shatat M, Sayed D, et al. Prevalence of Occult Hepatitis B Virus Infection in Hemodialysis Patients from Egypt with or without Hepatitis C Virus Infection. Hepat Mon. 2012;12(4):253-8.

3. Habibollahi P, Safari S, Daryani NE, Alavian SM. Occult hepatitis $B$ infection and its possible impact on chronic hepatitis $\mathrm{C}$ virus infection. Saudi J Gastroenterol. 2009;15(4):220-4.

4. Dimitroulopoulos D, Elefsiniotis I, Pavlidis C, Xinopoulos D, Tsamakidis K, Patsavela S, et al. European vs. Egyptian HCV-4 Patients with Elevated Baseline HCV RNA, Treated with PEG-IFNalpha2a and Ribavirin: The Role of Rapid and Early Virologic Response. Hepat Mon. 2010;10(3):193-8.

5. Hollinger FB, Sood G. Occult hepatitis B virus infection: a covert operation.J Viral Hepat. 2010;17(1):1-15.

6. Alavian SM, Einolahi B, Sadeghi-Gahroodi M, Hosseini SM. [Liver enzymes level evaluation in renal tranplanted group]. Modarres J Med Sci. 2002;5(1):87-92.

7. Alavian SM, Tabatabaei SH, Mahboobi N. Epidemiology and risk factors of $\mathrm{HCV}$ infection among hemodialysis patients in countries of the Eastern Mediterranean Regional Office of WHO (EMRO): a quantitative review of literature. J Public Health (Oxf). 2011:19:191-203. 